УДК 339.543.64(571.54:517.3)

DOI dx.doi.org/10.24866/1813-3274/2020-1/30-45

\begin{abstract}
Э. В. Батунаев ${ }^{1}$, Институт монголоведения, буддологии и тибетологии Сибирского отделения Российской академии наук, г. Улан-Удэ, Россия E-mail: вatunaeveduard@mail.ru
\end{abstract}

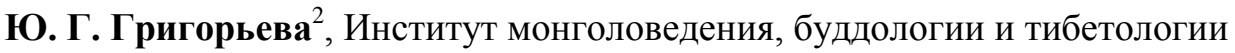
Сибирского отделения Российской академии наук, г. Улан-Удэ, Россия E-mail: grigoreva-yulia23@mail.ru

\title{
ПРИГРАНИЧНОЕ СОТРУДНИЧЕСТВО РОССИИ И МОНГОЛИИ (НА ПРИМЕРЕ РЕСПУБЛИКИ БУРЯТИЯ)*
}

Аннотация. В статье рассматриваются основные направления, тенденции и перспективы приграничного и регионального сотрудничества Монголии и России (на примере Республики Бурятия). Дан исторический экскурс приграничного сотрудничества, который позволил реконструировать давние торгово-экономические и добрососедские связи между Россией и Монголией. На основе статистических данных по состоянию на 2018-2019 гг. проведён анализ динамики двухстороннего торгового оборота, инвестиционного сотрудничества и современного состояния торгово-экономического сотрудничества Республики Бурятия и Монголии. Установлено, что в рамках реализации трёхстороннего экономического коридора «Россия - Монголия - Китай» приграничное сотрудничество между Монголией и Республикой Бурятия имеет высокий потенциал экономического и инвестиционного развития. Особое внимание уделяется существующим препятствиям в приграничном российско-монгольском сотрудничестве и анализируются пути их преодоле-

\footnotetext{
1 Эдуард Владимирович Батунаев, кандидат исторических наук, научный сотрудник, Институт монголоведения, буддологии и тибетологии Сибирского отделения Российской академии наук, г. Улан-Удэ, Россия.

2 Юлия Геннадьевна Григорьева, кандидат исторических наук, младший научный сотрудник, Институт монголоведения, буддологии и тибетологии Сибирского отделения Российской академии наук, г. Улан-Удэ, Россия.

Для цитирования: Батунаев Э. В., Григорьева Ю. Г. Приграничное сотрудничество России и Монголии (на примере Республики Бурятия) // Азиатско-Тихоокеанский регион: экономика, политика, право. 2020. № 1. С. 30-45.

* Работа выполнена при поддержке программы фундаментальных исследований СО РАН ХІІ.191.1.2. Межкультурное взаимодействие, этнические и социально-политические процессы в Центральной Азии, № AАAА-A17-117021310264-4.
}

(C) Батунаев Э. В., Григорьева Ю. Г., 2020 
ния. Сделан вывод, что Республика Бурятия среди приграничных регионов РФ является основным торгово-экономическим партнёром Монголии, развивает культурные, образовательные и гуманитарные связи.

Ключевые слова: Россия, Монголия, Республика Бурятия, приграничное сотрудничество, свободная торговая зона «Алтанбулаг», внешнеторговый оборот, экспорт, импорт, инвестиционное сотрудничество, гуманитарное сотрудничество, конкуренция, регион, интеграционные процессы, внешнеэкономические связи, производство, туризм, образование, регион, экология, глобализация.

\section{Eduard V. Batunaev ${ }^{1}$}

Institute for Mongolian, Buddhist and Tibetan Studies, Russian Academy of Science, Siberian Branch, Ulan-Ude, Russia

E-mail: batunaeveduard@mail.ru

\section{Yulia G. Grigorieva ${ }^{2}$}

Institute for Mongolian, Buddhist and Tibetan Studies, Russian Academy of Science, Siberian Branch, Ulan-Ude, Russia

E-mail: grigoreva-yulia23@mail.ru

\section{CROSS-BORDER COOPERATION BETWEEN RUSSIA AND MONGOLIA (ON THE EXAMPLE OF THE REPUBLIC OF BURYATIA)*}

Abstract. The article discusses the main directions, trends and prospects of crossborder and regional cooperation between Mongolia and Russia (on the example of the Republic of Buryatia). A historical excursion of cross-border cooperation was given, which made it possible to reconstruct the long-standing trade, economic and goodneighborly ties between Russia and Mongolia. Based on statistical data, an analysis of the dynamics of bilateral trade, investment cooperation and the current state of trade and economic cooperation of the Republic of Buryatia and Mongolia was carried out. It has been established that in the context of implementing the trilateral economic corridor of «Rus-

\footnotetext{
${ }^{1}$ Eduard V. Batunaev, candidate of historical sciences, researcher, Institute for Mongolian, Buddhist and Tibetan Studies, Russian Academy of science, Siberian Branch.

${ }^{2}$ Yulia G. Grigorieva, candidate of historical sciences, junior researcher, Institute for Mongolian, Buddhist and Tibetan Studies, Russian Academy of science, Siberian Branch.

For citing: Batunaev E. B., Grigorieva Yu. G. Cross-border cooperation between Russia and Mongolia (on the example of the Republic of Buryatia) // PACIFIC RIM: Economics, Politics, Law. 2019. № 3. P. 30-45.

* This work was supported by the basic research program of the SB RAS XII.191.1.2. Intercultural interaction, ethnic and socio-political processes in Central Asia, No. AAAA-A17-117021310264-4.
} 
sia-Mongolia-China», cross-border cooperation between Mongolia and the Republic of Buryatia has a high potential for economic development. Attention has been paid to the existing obstacles in the cross-border Russian-Mongolian cooperation and the ways of overcoming them. It is concluded that the Republic of Buryatia among the border regions is the main trade and economic partner of Mongolia, and develops cultural, educational and humanitarian ties.

Key words: Russia, Mongolia, the Republic of Buryatia, cross-border cooperation, free trade zone "Altanbulag", foreign trade turnover, export, import, investment cooperation, humanitarian cooperation, competition, region, integration processes, foreign economic relations, production, tourism, education, region, ecology, globalization.

\section{История российско-монгольского приграничного сотрудничества}

Россия и Монголия имеют многовековой опыт политического, торговоэкономического и культурного взаимодействия. Внешняя Монголия с 1691 г. входила в состав Цинской империи, и русско-монгольские отношения развивались на основе договоров между Российской Империей и Китаем - Нерчинского (1689 г.), Буринского и Кяхтинского (1727 г.). Включив Монголию в состав Цинской империи, маньчжуры создали на её территории особую систему управления. Монголия была наводнена китайскими купцами, которые контролировали китайский рынок. Китайские купцы были представлены здесь крупными фирмами, оказывавшими, со своей стороны, сильное давление на китайское правительство, требуя не допустить русских купцов в Монголию. Поэтому русская торговля в Монголии в этот период нами рассматривается как часть русскокитайской торговли. Важную роль в двусторонних связях играли русские купцы, заинтересованные в монгольском рынке. Они сопровождали первый состав русского консульства в Монголию [5, с. 5].

Россия экспортировала в Монголию «выделанные кожи, мануфактурные, бакалейные, галантерейные товары, железные и медные изделия, железо, эмалированные и фарфоровые изделия, маральи рога, в незначительном количестве хлебные продукты, табачные изделия и русские вина, укупорочные материалы, гамбургское серебро и русские кредитные билеты [10]. Русский текстиль уступал по качеству иностранному (английскому) и не выдерживал с ним конкуренции на монгольском рынке, поэтому многие купцы вынуждены были торговать иностранным текстилем, приобретая его в странах Запада или у китайцев.

Основными статьями российского импорта в 1906 г. являлись «мытая верблюжья и баранья шерсть, тарбаганьи (сурковые) шкурки, конская грива, разные шкуры, пушнина, лисьи, хорьковые шкурки, бараны, крупный рогатый скот, лошади, коровье масло, в незначительном количестве кирпичный чай, мелкие ки- 
тайские товары, войлок». Только через Тункинскую долину в г. Иркутск ежегодно прогонялся монгольский скот на общую сумму более 1 млн руб. [16].

Основную конкуренцию русским купцам на монгольском рынке составляли китайские торговцы, завозившие товары западных стран и выступавшие в качестве посредников иностранных фирм [15, с. 9]. Русско-китайская торговля осуществлялась главным образом через «восточные ворота» в Азию - торговую слободу Кяхта. На этот основной центр торговли в Восточной Сибири приходилось 67 \% товарооборота России с азиатскими странами [6, с. 241].

В XIX в. доходы Кяхты от русско-китайской торговли составляли более 16 млн рублей, а количество зарегистрированных фирм и компаний достигало 58 [4, с. 118]. Что касается общего оборота русской торговли в Монголии, то в 1903 г. он составлял составил 4 млн руб. До открытия морских портов и строительства Транссибирской железной дороги Кяхта являлась основным транзитным пунктом Великого чайного пути.

По другую сторону границы, в трёх километрах от Кяхты, располагался китайский город Маймачен, где активно шла русско-китайская и русско-монгольская торговля. В 1921 г., после захвата города частями Монгольской Народной армии под командованием Д. Сухэ-Батора, он получил название Алтанбулаг и стал одним из центров сосредоточения революционных сил.

Выгодное географическое положение на пересечении транзитных путей из Азии в Европу, а также развитие российско-монгольских торговых связей позволили исследователям рассматривать Маймачен как прообраз свободной торговой зоны «Алтанбулаг». Построенный на месте легендарного Маймачена XVIII - начала $\mathrm{XX}$ вв., «Алтанбулаг» в перспективе может стать полюсом роста национального хозяйства страны и приграничных регионов Сибири [8, с. 141].

После достижения Монголией независимости русско-монгольская торговля регулировалась русско-монгольским соглашением 1912 г. Монгольское правительство предоставило русским купцам права и преимущества, которые были перечислены в прилагавшемся торговом протоколе, и обязалось не предоставлять другим иностранным подданным больших прав, чем те, которыми пользовались русские [12, с. 82].

Иными словами, русско-монгольское соглашение 1912 г. и протокол к нему максимально благоприятствовали русской торговле, что обусловило её заметный рост: в 1911 г. ввоз русских товаров в Монголию составлял 2115 тыс. р., вывоз 758 тыс. р. а в 1915 г., соответственно, 11451 тыс. р. и 2429 тыс. p. [16, с. 166].

Необходимо отметить, что российско-монгольские отношения прошли сложные этапы становления и развития. В дореволюционный период Россия оказала помощь Монголии в сохранении её независимости, а в советские времена выступала в роли покровителя, оказывала военную, материальную и финансовую помощь братской республике. Во времена СССР внешнеторговые и экономические связи полностью планировались из союзного центра. В начале 1990-х гг. во внешней политике 
РФ наблюдались определённая недооценка её восточного направления и ослабление внимания к отношениям с традиционными дружественными партнёрами.

В постсоциалистический период переориентация на приграничное сотрудничество была вызвана свёртыванием в большей степени межгосударственного сотрудничества и закономерной реакцией на экономический кризис. Соответственно основную роль в сохранении и развитии сотрудничества пришлось играть приграничным регионам Сибири $[1$, с. 86$]$.

Лишь в конце последнего десятилетия XX в. связи России и Монголии стали возрождаться, выстраиваясь на принципах равноправия.

В настоящее время основная доля торговли между Россией и Монголией приходится на Иркутскую область, Забайкальский край, Республику Бурятия, Алтай и Тыву. Необходимо отметить, что инструментом двустороннего сотрудничества являются представительства Иркутской, Новосибирской, Кемеровской областей, Забайкальского края, республик Бурятия, Алтай, Тыва и г. Москвы, а с монгольской стороны - генеральные консульства в Иркутске, Улан-Удэ и Кызыле, консульство в Элисте, а также институт почётных консулов в ряде сибирских городов. Все представительства работают в тесном сотрудничестве с торгово-промышленными палатами и посольствами России и Монголии.

Особое внимание представительства приграничных субъектов России уделяют проблемам укрепления материальной базы и увеличения пропускной способности 29 контрольно-пропускных пунктов на российско-монгольской границе, прежде всего 5 главных из них: в Кяхте, Шара Сумэ, Цагаан Толгойте, Хандагайте и Ташанте [11, с. 78].

Таким образом, современные российско-монгольские отношения развиваются поступательно и имеют тенденцию перехода на качественно новый уровень всеобъемлющего стратегического партнёрства. Вместе с тем хотелось бы отметить, что существенными препятствиями на пути развития российско-монгольских являются дисбаланс во взаимной торговле, высокие таможенные пошлины и сборы, транспортные расходы, различные санитарно-ветеринарные ограничения на ряд монгольских экспортных товаров. В этих условиях России необходимо перейти во многом от декларативного характера двусторонних отношений к реальным шагам и интенсифицировать усилия в политической, торгово-экономической, образовательной и культурно-гуманитарных сферах.

\section{Торгово-экономическое сотрудничество Республики Бурятия с Монголией на современном этапе}

У Бурятии с Монголией давние исторические связи. Сотрудничество Республики Бурятия и Монголии осуществляется в рамках Соглашения между Правительством Российской Федерации и Правительством Монголии об экономическом и 
приграничном сотрудничестве между Республикой Бурятия и Монголией от 25 февраля 1999 г. и развивается по различным направлениям экономики и гуманитарной сферы. Приграничное сотрудничество осуществляется в традиционных сферах: внешняя торговля, инвестиционное сотрудничество, проведение совместных мероприятий в сфере сельского хозяйства, охраны окружающей среды, туризма и спорта, образования и науки, культуры и здравоохранения.

Основную статью импорта из Монголии составляют мясо и пищевые субпродукты. Наибольший объём поставок мяса был в 2001-2002 гг. (до 14,17 тыс. т), затем импорт значительно сократился и в 2008 г. составил всего 3,48 тыс. т. Резкое падение, особенно за 2003-2007 гг., было вызвано хронической задержкой платежей со стороны ОАО «Бурятмясопром», а также неблагоприятной эпизоотической обстановкой в Монголии. Структура бурятского экспорта в Монголию представлена продовольственными товарами, машиностроительной продукцией: авиатехника, оборудование и электрические машины $(44,1 \%$ в 2008 г.). Основную долю в общем объёме экспорта продовольствия занимает мука $-34,7$ тыс. т на сумму 15,3 млн [2, с. 34].

Из прочих видов продовольственных товаров можно отметить экспорт 4,2 тыс. т молочной продукции, 0,81 тыс. т мучных кондитерских изделий. Кроме того, в 2006 г. было отгружено 30,62 тыс. куб. м необработанных лесоматериалов, 0,3 тыс. т пиломатериалов, 3,6 тыс. т лома чёрных металлов, машиностроительной продукции на 5,7 млн долл. [11, с. 202].

Внешнеторговый оборот Республики Бурятия в 2018 г. составил 1 054,8 млн долларов США и по сравнению с 2017 г. увеличился на 215,7 млн долларов США (на 25,7\%). Республика Бурятия осуществляла внешнюю торговлю с партнёрами из 60 стран мира (в 2017 г. - из 54 стран). По сравнению с 2017 г. товарооборот со странами дальнего зарубежья увеличился на $26,5 \%$, а со странами СНГ - уменьшился на 8,0\% и составил соответственно 1 037,3 млн долларов США (98,3\% от общего объема товарооборота) и 17,5 млн долларов США (1,7\%) (табл. 1).

По итогам 2018 г. Монголия занимала 6-е место в обороте внешней торговли республики. Среди российских регионов Республика Бурятия занимает 6-е место по объёмам экспорта в Монголию [7].

Внешнеторговое сотрудничество с Монголией отличается разнообразием торгово-экономических связей и широким ассортиментом поставляемой продукции. В течение последних трёх лет отмечается стабильный рост объёмов внешнеторгового оборота республики с Монголией со среднегодовым темпом роста выше $11 \%$, положительная динамика наблюдается в 2018 г. и во взаимной торговле России с Монголией [14].

Так, внешнеторговый оборот Республики Бурятия с Монголией в 2018 г. составил 44,9 млн долл. США с ростом к 2017 г. на 9,7\% (табл. 2). 
Товарооборот Республики Бурятия по странам основным торговым партнёрам в 2018 г.

\begin{tabular}{|l|c|c|c|}
\hline \multicolumn{1}{|c|}{ Страна } & $\begin{array}{c}\text { Стоимость, } \\
\text { тыс. долларов США }\end{array}$ & Уд. вес, \% & $\begin{array}{c}2018 \text { г. в \% } \\
\text { к 2017 г. }\end{array}$ \\
\hline $\begin{array}{l}\text { Всего } \\
\text { в том числе: }\end{array}$ & $\mathbf{1 0 5 4 7 6 1 . 5}$ & $\mathbf{1 0 0 . 0}$ & $\mathbf{1 2 5 . 7}$ \\
\hline Китай & 394225.6 & 37.4 & 132.4 \\
\hline Япония & 198347.4 & 18.8 & 132.0 \\
\hline Республика Корея & 139350.7 & 13.2 & 106.9 \\
\hline Тайвань (Китай) & 82157.9 & 7.8 & 99.9 \\
\hline Перу & 66443.9 & 6.3 & 69.3 \\
\hline Монголия & 44876.7 & 4.3 & 109.7 \\
\hline Индия & 28913.6 & 2.7 & 136.9 \\
\hline Вьетнам & 21418.6 & 2.0 & 142.7 \\
\hline Гонконг & 20480.7 & 1.9 & 105.6 \\
\hline Малайзия & 18358.3 & 1.7 & \\
\hline Прочие & 40170.1 & 3.9 & \\
\hline
\end{tabular}

Источник: Дальневосточное таможенное управление (http://dvtu.customs.ru/statistic/res publika-buryatiya)

Таблицуа 2

Динамика внешней торговли Республики Бурятия с Монголией

(тыс. долл. США)

\begin{tabular}{|l|c|c|c|c|}
\hline \multicolumn{1}{|c|}{ Наименование } & $\mathbf{2 0 1 6}$ & $\mathbf{2 0 1 7}$ & $\mathbf{2 0 1 8}$ & $\begin{array}{c}\mathbf{1} \text { квартал } \\
\mathbf{2 0 1 9}\end{array}$ \\
\hline $\begin{array}{l}\text { Внешнеторговый обо- } \\
\text { рот Республики Буря- } \\
\text { тия с Монголией }\end{array}$ & $\mathbf{3 4 6 0 4 , 0}$ & $\mathbf{4 0 9 1 3 , 7}$ & $\mathbf{4 4 8 7 6 , 6}$ & $\mathbf{7 5 8 3 , 7}$ \\
\hline Темп роста, (\%) & 107,4 & 118,2 & 109,7 & 87,9 \\
\hline Экспорт & $\mathbf{2 8 9 0 2 , 7}$ & $\mathbf{3 3 6 9 0 , 8}$ & $\mathbf{3 6 ~ 3 1 4 , 9}$ & $\mathbf{6 6 9 8 , 0}$ \\
\hline Темп роста, (\%) & 110,7 & 116,6 & 107,8 & 90,1 \\
\hline Импорт & $\mathbf{5 7 0 1 , 3}$ & $\mathbf{7 2 2 2 , 9}$ & $\mathbf{8 5 6 1 , 7}$ & $\mathbf{8 8 5 , 7}$ \\
\hline Темп роста, (\%) & 93,3 & 126,7 & 118,5 & 73,7 \\
\hline
\end{tabular}

Источник: Территориальный орган Федеральной службы государственной статистики по Республике Бурятия (https://burstat.gks.ru/), Министерство экономики Республики Бурятия (https://egov-buryatia.ru/minec/) 
Согласно данным Федеральной таможенной службы, экспорт Республики Бурятия в Монголию вырос на 7,8\% относительно 2017 г. и составил 36,3 млн долл. США. Основной причиной стало увеличение поставок древесины и картона на $93 \%$ (+2,2 млн долл. США), металлических изделий на 0,4 млн долл. США (+19,3\%), текстильных изделий на 0,3 млн долл. США (+29,4\%) [9].

Продовольственные товары и сельскохозяйственное сырьё являются одной из наиболее значимых товарных групп бурятского экспорта. Поставки по данной группе товаров, составляющей основу экспорта, выросли на 2,5\% и составили 17,3 млн долл. США. В Монголию экспортируется широкая линейка продуктов питания, как местных производителей, так и российского производства. В 2018 г. было вывезено молочной продукции - 472,7 тонн, жиров и масел $-2,5$ тыс. тонн, яиц 3,3 тыс. тонн, продуктов из мяса и рыбы - 669,0 тонн. Кроме того, с начала 2018 г. осуществляются поставки свинины на экспорт в Монголию, объём которых составил 479,3 тонн [3].

Ежегодно из Бурятии в Монголию осуществляются поставки племенного крупного рогатого скота, пчелосемей, семян районированных сортов пшеницы, картофеля, овощей, саженцев плодово-ягодных культур. Ведётся работа по поставкам в Монголию запасных частей к подвижному составу АО «Улан-Баторская железная дорога», производимых на Улан-Удэнском ЛВРЗ - филиале ОАО «Желдорреммаш», ОАО «Селенгинский целлюлозно-картонный комбинат» осуществляет поставки в Монголию тарного и гофрированного картона, ООО «Литейщик» Закаменского района производит и экспортирует запасные части к оборудованию для нужд горнодобывающих компаний Монголии.

Импортные поставки из Монголии в 2018 г. по сравнению с 2017 г. увеличились на $18,5 \%$, достигнув уровня 8,6 млн долл. США за счёт увеличения поставок конины и говядины. В первом квартале 2019 г. объём внешнеторгового оборота Республики Бурятия с Монголией сократился на $12,1 \%$ по сравнению с аналогичным периодом 2018 г. и составил 7,6 млн долл. США. По итогам 3 месяцев 2019 г. доля Монголия занимает 4,0\% от всего объёма внешней торговли Бурятии [13].

Стоимостной объём экспортных поставок в Монголию в первом квартале 2019 г. составил 6,7 млн долл. США с сокращением на 9,9\% по сравнению с первым кварталом прошлого года. Основное влияние на снижение экспортных поставок оказало сокращение поставок по группе товаров «Продовольственные товары и сельскохозяйственное сырьё» на 23,6\% (-1,0 млн долл. США), в том числе поставок мяса свинины, мучных изделий, отрубей [13].

Импортные поставки из Монголии в отчётном периоде по сравнению с аналогичным периодом 2018 г. снизились на 26,3\% и составили 0,9 млн долл. США. Сокращение объёма внешней торговли в первом квартале 2019 г. обусловлено вводом временных ограничений на экспорт свиней и продукции из свинины в Россий- 
скую Федерацию со всей территории Монголии с 31 января 2019 г. по 6 февраля 2019 г. в целях предупреждения распространения африканской чумы свиней.

Большое внимание со стороны Республики Бурятия и Монголии в развитии торгово-экономического сотрудничества уделяется межгосударственным встречам, в которых участвуют не только неправительственные структуры, а также бизнесмены и общественные деятели.

Так, в январе 2018 г. по приглашению мэра г. Улан-Батор Сундуйн Батболда, Межпарламентской группы Великого Государственного Хурала (ВГХ) Монголии «Россия - Монголия», при содействии Национальной Торгово-промышленной палаты Монголии (НТПП) состоялся визит в Монголию делегации деловых кругов Республики Бурятия под руководством Главы Республики Бурятия - Председателя Правительства Республики Бурятия А. С. Цыденова для участия в бизнесконференции «Инвестиционный потенциал Республики Бурятия. В мероприятиях в рамках бизнес-конференции приняли участие Посол России в Монголии И. Азизов, заместитель председателя Межпарламентской группы «Россия - Монголия» Великого Государственного Хурала (ВГХ) Монголии Бямбасүрэнгийн Энх-Амгалан, Президент Национальной Торгово-промышленной палаты Монголии Баатаржавын Лхагважав и др.

Всего в мероприятиях участвовало около 700 человек, представляющих более 40 компаний Республики Бурятия, более 300 компаний Монголии, а также компании Китая, Казахстана, Республики Корея, Германии. По результатам мероприятия были обсуждены вопросы поставок в Монголию электроэнергии, организации транзитных железнодорожных и автомобильных перевозок, развития медицинского сотрудничества, туризма, поставок из Монголии мяса. В рамках визита состоялись встречи Главы Республики Бурятия А. С. Цыденова с Президентом Монголии Халтмаагийн Баттулгой, Председателем Правительства Монголии Ухнаагийн Хурэлсухом, вице-спикером Великого Государственного Хурала Монголии Лувсанцэрэнгийн Энх-Амгаланом, членами Межпарламентской группы «Россия - Монголия», а также мэром города Улан-Батор Сундуйн Батболдом.

В апреле 2018 г. состоялся визит делегации Народного Хурала (HX) Республики Бурятия во главе с Председателем НХ РБ Ц-Д.Э. Доржиевым в Монголию. Депутаты ознакомились с работой группы компаний APU, посетили ряд предприятий, обсудили вопросы инвестиционного сотрудничества.

В период с 10 по 11 мая 2018 г. в г. Улан-Удэ проведена бизнес-конференция деловых кругов Республики Бурятия и Монголии. В рамках мероприятия Республику Бурятия посетили руководители около 170 компаний города Улан-Батора и аймаков Монголии, работающих в сфере пищевой, лёгкой промышленности, энергетики, транспорта, строительства и сельского хозяйства. Делегацию Монголии возглавили член Великого Государственного Хурала Монголии, Председатель 
Батунаев Э. В., Григорьева Ю. Г. Приграничное сотрудничество России и Монголии (на примере Республики Бурятия)

Межпарламентской группы «Монголия - Бурятия» Н. Оюундарь, Госсекретарь Министерства продовольствия, сельского хозяйства и легкой промышленности Монголии Д. Энхбат и генеральный секретарь Национальной Торгово-промышленной палаты Монголии Э. Оюунтэгш.

Проведены презентации экономического потенциала Монголии и Республики Бурятия, организованы встречи предпринимателей по секциям: агропромышленный комплекс, транспортно-логистический комплекс, промышленность, лечебнооздоровительный туризм. Также предприниматели Бурятии и Монголии провели переговоры в формате $\mathrm{b} 2 \mathrm{~b}$, презентации своих предприятий и проектов, посетили промышленные предприятия и организации Республики Бурятия: фанерный завод «Ольхон», фабрику «Амта», рыбозавод «Байкал», фабрику «Селенга», кондитерский цех «Кондитерские истории», предприятие по монтажу автоматических ворот «Ворота Улан-Удэ», компанию «Ажур Текс» по производству бельевого и детского трикотажа, спортивной и домашней одежды и чулочно-носочных изделий, компанию «Развивайка», производящую детские игрушки и модули, Бурятский научноисследовательский институт сельского хозяйства.

В период с 7 по 9 июня 2018 г. делегация Республики Бурятия во главе с заместителем председателя Правительства Республики Бурятия по экономическому развитию И. И. Зураевым приняла участие в форуме «Российско-монгольская инициатива-2018» в г. Улан-Батор. В состав делегации входили представители Торгово-промышленной палаты Республики Бурятия, Центра экспорта Бурятии, Фонда поддержки малого предпринимательства, компаний агропромышленного комплекса. В рамках форума проведена выставка с участием передовых технологий, оборудования и продукции малых и средних предпринимателей России, в том числе из Республики Бурятия: ООО «МИП Байкалия», ООО «Облепиховый рай», ООО «Кондитерский цех Берёзка», ИП Беломестнов А.Г., ООО ТРЦ «Окинский». Представители бизнеса республики провели презентацию своих компаний и выпускаемой продукции для бизнесменов Монголии и монгольских покупателей. ООО кондитерский цех «Берёзка» (г. Улан-Удэ) провёл дегустацию линейки новых тортов, производимых в Бурятии, ООО «Облепиховый рай» (Селенгинский район, п. Темник) представил соки, сиропы, джемы из облепихи, ООО ТРЦ «Окинский» (г. Улан-Удэ) - столовое куриное яйцо и др., ООО «МИП Байкалия» (г. УланУдэ) - травяные чаи из чаги, Иван-чая, и др., ИП Беломестнов А.Г. (Джидинский район, с. Петропавловка) - полимерную тротуарную плитку. По итогам выставки заключены контракты на поставку в Монголию выпускаемой в Республике Бурятия продукции, проведены переговоры с сетевыми торговыми компаниями о возможности поставок продуктов питания в Монголию.

В соответствии с приглашением министра продовольствия, сельского хозяйства и легкой промышленности Монголии Б. Батзориг, делегация Министерства 
сельского хозяйства и продовольствия Республики Бурятия в июне 2018 г. приняла участие в VIII Международной встрече многостороннего партнёрства по Глобальной программе устойчивого развития животноводства в г. Улан-Батор. В рамках встречи были обсуждены вопросы поставок мяса из Монголии в Республику Бурятия, поставок племенных животных, саженцев, семян, пищевой продукции из Республики Бурятия в Монголию, организации ярмарок и выставок российских и монгольских товаров.

В период 13-16 апреля 2018 г. в г. Иркутске с участием представителя Министерства природы Республики Бурятия проведено заседание российско-монгольской рабочей подгруппы «Научное сопровождение разработки материалов для комплексного рассмотрения вопросов, связанных с планируемым строительством в Монголии гидротехнических сооружений на водосборной территории реки Селенга». На заседании рабочей подгруппы рассмотрены предложения для доработки проекта «Предварительный вариант технического задания на проведение РЭО района бассейна р. Селенга и оз. Байкал в контексте проекта строительства Шуренской ГЭС и проектов развития гидроэнергетики и водоотвода «Орхон». По результатам заседания стороны выразили готовность продолжить обсуждение проектов гидротехнических сооружений, планируемых на р. Селенга и её притоках на любых дискуссионных площадках.

В декабре 2018 г. Фондом регионального развития Республики Бурятия в г. Улан-Удэ проведена бизнес-конференция «День инвестора в Республике Бурятия», участие в которой приняли предприниматели Монголии. На площадке Фонда регионального развития Республики Бурятия проведены переговоры с монгольской компанией APU по открытию представительства компании в Бурятии, учреждению акцизного склада и склада временного хранения (CBX). Также проведены переговоры с монгольской компанией TESO по проекту строительства макаронной фабрики Теso Corporation в Бурятии. Ведётся работа по подбору земельных участков и помещений для строительства или размещения макаронной фабрики с учётом предъявляемых требований к производству. Фондом регионального развития Республики Бурятия прорабатывается возможность реализации проекта «Создание центра обработки грузов e-commerce» с привлечением монгольской стороны. Определена в качестве участника проекта монгольская транспортная компания «Туушин».

В период 28-29 марта 2019 г. в Республике Бурятия, в целях дальнейшего развития сотрудничества между субъектами малого и среднего предпринимательства России и Монголии, проведена Российско-Монгольская бизнес-миссия. Монгольскую делегацию возглавил Государственный секретарь Министерства иностранных дел Монголии Д. Даваасурэн.

В составе монгольской делегации приняли активное участие представители различных министерств и ведомств, бизнес-сообществ, осуществляющих деятель- 
ность в сферах туризма, строительства, транспорта и логистики, рыборазведения и др. В рамках Российско-Монгольской бизнес-миссии проведены выставка-ярмарка монгольских и российских товаров «Baikaltrade 2019», презентации организаций; представители деловых кругов участвовали в бирже контактов предпринимателей и в работе по секциям в сферах агропромышленного комплекса, строительства, транспорта, логистики.

Предприниматели Монголии посетили ряд предприятий агропромышленного комплекса республики, промышленный парк, фабрику по обработке нефрита «Ориентал Вэй», а также получили консультации по вопросам соблюдения требований ветеринарного и фитосанитарного надзора.

В мае 2019 г. организации Республики Бурятия: АО «Улан-Удэнская птицефабрика», ООО «Аква», ООО «Агрохимсервис Бурятия», арт-студия «Домбо», малое инновационное предприятие «Байкалия», ОАО «Бурятхлебпром», сеть магазинов «Униформа», питомник «Тохойские саженцы» и другие, приняли участие в Международной выставке продукции экспорта и импорта в г. Улан-Батор. Проведены переговоры с монгольскими компаниями, достигнута договорённость об установлении партнёрских связей.

В рамках расширения торгово-экономических связей Республики Бурятия с Монголией в области агропромышленного комплекса перспективными направлениями сотрудничества являются:

- расширение поставок пищевой продукции из Республики Бурятия Российской Федерации в Монголию;

- поставки племенного материала из Республики Бурятия Российской Федерации в Монголию;

- активизация сотрудничества между уполномоченными органами по вопросу снятия ограничений на ввоз говядины на кости из Монголии в Российскую Федерацию;

- проведение выставочно-ярмарочных мероприятий на территориях Российской Федерации и Монголии;

- организация совместных производств на территории Республики Бурятия Российской Федерации.

Таким образом, можно сделать вывод, что внешнеторговое сотрудничество с Монголией активно развивается, особенно в последние годы. Торговоэкономические отношения между Республикой Бурятией и Монголией отличаются разнообразием торгово-экономических связей и широким ассортиментом поставляемой продукции. Основу экспортных поставок Республики Бурятия в Монголию составляют поставки рыбной, хлебной продукции и мучных кондитерских изделий, племенной скот. Приоритетным направлением в развитии сотрудничества по поставке из Монголии в РБ остаются поставки мяса говядины и конины для промыш- 
ленной переработки. Сдерживающим фактором в поставке мясосырья из Монголии на сегодняшний день также является высокая стоимость монгольского мяса, не выдерживающая ценовой конкуренции с продукцией из других стран и зачастую превосходящая внутренние российские цены.

Основной проблемой в приграничном сотрудничестве между Республикой Бурятия и Монголией на сегодня является эпизоотическая ситуация в Монголии. На протяжении длительного времени Монголия остается неблагополучной по ящеру, бруцеллёзу, сибирской язве, оспе коз, сапу, инфекционной анемии лошадей, туберкулёзу рогатого скота и т.д. Существующие ограничения на ввоз из Монголии крупного рогатого скота, лошадей и мелкого рогатого скота из-за высоких эпизоотических рисков не могут быть отменены до стабилизации эпизоотической обстановки в Монголии.

В настоящий момент основной акцент в развитии торгово-экономического сотрудничества сделан на решение вопросов о продвижении продукции бурятских товаропроизводителей на монгольский рынок. Подготовлен перечень потенциальных экспортёров Бурятии в сфере АПК с описанием продукции и объёмами поставок для предложения монгольской стороне.

Таким образом, российско-монгольские отношения в своей истории прошли сложные этапы становления и развития. В дореволюционный период Россия оказала помощь в сохранении независимости Монголии, а затем, в советский период, выступала в роли защитника, донора, оказывала военную, материальную помощь братской республике. В 1990-х гг,, с началом кардинальных реформ и изменений в социально-политической и политической сферах общества, Россия и Монголия погрузились в жесточайший кризис. Начиная с конца 1990-х гг. происходит постепенное восстановление двусторонних отношений России и Монголии на новых принципах равноправного партнёрства.

В настоящее время двусторонние отношения выведены на новый уровень всеобъемлющего стратегического партнёрства. В этой связи приграничные территории выполняют особую миссию по налаживанию эффективного межгосударственного взаимодействия и сотрудничества. Бурятия как приграничный регион имеет давнюю историю, основанную на экономических, политических, культурных, гуманитарных связях.

Анализ торгово-экономического сотрудничества между Монголией и Бурятией показывает, что есть высокий потенциал торгово-экономического развития и инвестиционного сотрудничества. Особое внимание обеих сторон привлекают возможности инвестиционного сотрудничества с созданием на российско-монгольской границе свободной торговой зоны «Алтанбулаг». Одним из перспективных направлений сотрудничества Монголии и Бурятии является развитие туризма. Развивается сотрудничество в образовательной сфере. 
Вместе с тем, существуют препятствия для эффективного приграничного сотрудничества Бурятии и Монголии - это узость номенклатуры экспортных товаров, высокие таможенные тарифы на традиционные экспортные товары, высокие фитосанитарные и ветеринарные требования для экспорта монгольской мясной продукции, конкуренция Бурятии с другими российскими регионами. Необходимо сохранять накопленный потенциал и двигаться вперёд, активно вовлекаться в процесс взаимодействия на межгосударственном и региональном уровнях, а также активно развивать горизонтальные связи между аймаками - районами, городами, культурными и образовательными учреждениями.

\section{Список литературы}

1. Атанов, Н. И. Приграничное сотрудничество России с Монголией // Регион: экономика и социология. - 2009. - № 1. - С. 85-91.

2. Атанов, Н. И. Российско-монгольское сотрудничество в спектре приграничных взаимодействий / Н. И. Атанов, Б. Э. Намжилова // Вестник Бурятского научного центра Сибирского отделения Российской академии наук. - 2011. - № 1. C. $27-40$.

3. Внешнеэкономическая деятельность Республики Бурятия // Территориальный орган Федеральной службы государственной статистики по Республике Буpятия. - URL: https://burstat.gks.ru/ (дата обращения: 13.05.2020).

4. Евдокимова, С. В. Город завидной судьбы (к 275-летию г. Кяхты) // Вестник Бурятского университета. - 2003. - Вып. 6. - С. 115-126.

5. Единархова, Н. Е. Русские в Монголии: основные этапы и формы экономической деятельности (1861-1921 гг.). - Иркутск : Оттиск, 2003. - 252 с.

6. Кальмина, Л. В. Кяхта в 1840-1930 г.: блеск и нищета «окна в Китай» / Л. В. Кальмина, А. М. Плеханова // Власть. - 2019. - № 2. - С. 240-245.

7. Комплексный доклад «Социально-экономическое положение Республики Бурятия» // Территориальный орган Федеральной службы государственной статистики по Республике Бурятия. - URL: https://burstat.gks.ru/ (дата обращения: 13.05.2020).

8. Курас, Л. В. Монголия: «Алтанбулаг» - свободная торговая зона / Л. В. Курас, Б. Д. Цыбенов // Власть. - 2013. - Т. 21, № 2. - С. 141-144.

9. Общие итоги внешней торговли Республики Бурятия // Дальневосточное таможенное управление. - URL: http://dvtu.customs.ru/statistic/respublikaburyatiya/2018-god/document/176935 (дата обращения: 13.05.2020).

10. Российский государственный исторический архив (РГИА). Ф. 23. Оп.18. Д. 222. Л. 35-36.

11. Россия и Монголия на пути стратегического партнерства. - Москва : Ин-т востоковедения РАН, 2011. - 440 c. 
12. Сборник дипломатических документов по монгольскому вопросу. Санкт-Петербург, 1914. - 91 с.

13. Статистические данные // Министерство экономики Республики Бурятия. - URL: https://egov-buryatia.ru/minec/ (дата обращения: 13.05.2020).

14. Статистический ежегодник 2018 // Территориальный орган Федеральной службы государственной статистики по Республике Бурятия. - URL: https://burstat.gks.ru/ (дата обращения: 13.05.2020).

15. Суходолов А. П. Монголия и русско-монгольские отношения первой половины XX века: проблемы истории и историографии / А. П. Суходолов, Ю. В. Кузьмин. - Иркутск : Изд-во Байкал.ун-та, 2016. - 312 с.

16. Чимитдоржиев, Ш. Б. Россия и Монголия / Ш. Б. Чимитдоржиев. Москва : Восточная литература, 1987. - 239 с.

\section{References}

1. Atanov N.I. Prigranichnoe sotrudnichestvo Rossii s Mongoliei [Cross-border cooperation of Russia with Mongolia]. Region: ekonomika i sotsiologiya, 2009, no. 1, pp. 85-91.

2. Atanov N.I., Namzhilova B.E. Rossiisko-mongol'skoe sotrudnichestvo v spektre prigranichnykh vzaimodeistvii [Russian-Mongolian cooperation in the spectrum of cross-border interactions]. Vestnik Buryatskogo nauchnogo tsentra Sibirskogo otdeleniya Rossiiskoi akademii nauk, 2011, no. 1, pp. 27-40.

3. Foreign economic activity of the Republic of Buryatia. Territorial authority of the Federal State Statistics Service for the Republic of Buryatia. Available at: https://burstat.gks.ru/ (accessed 13 May 2020). (In Russian).

4. Evdokimova S.V. Gorod zavidnoi sud'by (k 275-letiyu g. Kyakhty) [The city of enviable fate (on the 275th anniversary of the city of Kyakhta)]. Vestnik Buryatskogo universiteta, 2003, iss. 6, pp. 115-126.

5. Edinarkhova N.E. Russkie v Mongolii: osnovnye etapy i formy ekonomicheskoi deyatel'nosti (1861-1921 gg.) [Russians in Mongolia: the main stages and forms of economic activity (1861-1921)]. Irkutsk : Ottisk Publ., 2003. 252 p.

6. Kal'mina L.V., Plekhanova A.M. Kyakhta v 1840-1930 g.: blesk i nishcheta «okna v Kitai» [Kyakhta in 1840-1930: the splendor and poverty of the "window to China"]. Vlast', 2019, no. 2, pp. 240-245.

7. Comprehensive report «Socio-economic situation of the Republic of Buryatia». Territorial authority of the Federal State Statistics Service for the Republic of Buryatia. Available at: https://burstat.gks.ru/ (accessed 13 May 2020). (In Russian).

8. Kuras L.V., Tsybenov B.D. Mongoliya: «Altanbulag» - svobodnaya torgovaya zona [Mongolia: «Altanbulag» - a free trade zone]. Vlast', 2013, vol. 21, no. 2, pp. 141-144. 
9. General results of foreign trade of the Republic of Buryatia. Far Eastern Customs Administration. Available at: http://dvtu.customs.ru/statistic/respublikaburyatiya/2018-god/document/176935 (accessed 13 May 2020). (In Russian).

10. Russian State Historical Archive (RGIA), Foundation 23, Inventory 18, Case 222, Lists 35-36. (In Russian).

11. Rossiya i Mongoliya na puti strategicheskogo partnerstva [Russia and Mongolia on the path of strategic partnership]. - Moscow: Institute of Oriental Studies of the Russian Academy of Sciences Publ., 2011. 440 p.

12. Sbornik diplomaticheskikh dokumentov po mongol'skomu voprosu [Collection of diplomatic documents on the Mongolian issue]. St-Petersburg, 1914. 91 p.

13. Statistical data. Ministry of Economy of the Republic of Buryatia. Available at: https://egov-buryatia.ru/minec/ (accessed 13 May 2020). (In Russian).

14. Statistical Yearbook 2018. Territorial Authority of the Federal State Statistics Service for the Republic of Buryatia. Available at: https://burstat.gks.ru/ (accessed 13 May 2020). (In Russia).

15. Sukhodolov A.P., Kuz'min Yu.V. Mongoliya i russko-mongol'skie otnosheniya pervoi poloviny KhKh veka: problemy istorii i istoriografii [Mongolia and RussianMongolian relations in the first half of the twentieth century: problems of history and historiography]. Irkutsk: Publishing house of Baikaluniversity, 2016. $312 \mathrm{p}$.

16. Chimitdorzhiev Sh.B. Rossiya i Mongoliya [Russia and Mongolia]. Moscow: Vostochnaya literature Publ., 1987. 239 p. 